Ann. Génét. Sél. anim., I972, 4 (I), 99-1 I6.

\title{
GENETIC ASPECTS OF MEAT QUALITY IN PIGS ( $\left.{ }^{1}\right)$
}

\author{
P. JONSSON, P. JENSEN and O. K. PEDERSEN \\ National Institute of animal Science, \\ Department for Experiments with Pigs and Horses, \\ 25, Rolighedsvej, 1958 Copenhagen V, Denmark
}

\begin{abstract}
SUMMARY
Danish investigations have shown that environmental conditions like season of year, temperature during transport, and carcass weight have, on an average of a larger sample of individuals, only a slight effect at least on the variance of meat colour in the muscle.

Investigations within many breeds of pigs, including those given in tables 7,8 , and Io, give estimates of additive gene effects of $h^{2}=0.3$ to $h^{2}=0.4$ for values of muscle colour and $45 \mathrm{mn} \mathrm{pH}$ values.

The genetic correlation between sexes in meat colour and in two other characters is given.

The phenotypic and genetic variability of characteristics related to meat quality are given together with objective carcass measurements, and the phenotypic and genetic relationship between these are discussed.

The possibility of being able to master, through a selection program, the problem of meat quality and the problem of stress adaptability related to this, is discussed.
\end{abstract}

\section{INTRODUC'TION}

Problems on meat quality have been reported as early as in I883, and in connection with a pork exhibition in Berlin HERTER and WILSDORF (I9I4) dealt with problems like meat with a pale, moist surface creating processing problems. These authors also dealt with breed differences in muscle colour. Already in the early days of the Danish bacon production the meat colour was taken into consideration, as the first director of the Danish pig progeny testing stations reported of complaints from Great Britain, indicating that occasionnally the Danish bacon had a poor, pale colour (BECK, I93I). A regulation was made requiring that all test carcasses should be scored for colour in $\mathrm{m}$. $L$. dorsi. This subjective colour grading covered an arbitrary five class scale given on the surface of the cross section of the m. L. dorsi behind the shoulder and another one in front of the ham.

(1) Invited report presented in the Study Meeting of the European Association for Animal Production, joint session of commission on Pig Production and commission on Animal Genetics, Versailles, France, July I 9 th, I $97 x$. 
In their description of acute heart problems associated with sudden death in pigs, FREDE (I926) and HUPKA (I939) used the designation " muscular degeneration " for the most pronounced cases of muscles with discolouration. LUDVIGSEN (I953, I954) described muscular discolouration in the Danish Landrace in connection with processing and canning problems and claimed that this discolouration involved both nutritional and genetic factors.

WISMER-PEDERSEN (I959) found a phenotypic correlation of $r_{\mathrm{P}}=-0.7 \mathrm{I}$ between the $\mathrm{pH}$ measurement in the $\mathrm{m}$. L. dorsi behind the last rib 45 minutes after killing and the water-holding capacity of this muscle. He also found a correlation of $r_{\mathrm{P}}=-0.86$ between the same $\mathrm{pH}$ value and the corresponding concentration of lactic acid. Clausen and NöRTOFT ThOMSEN (I960) associated a high acid content of the meat with pale colour characteristics and reported a correlation of $r_{\mathrm{P}}=+0.6$ between these traits.

WISMER-PEDERSEN and BRISkey (I96I) were able to produce pale, moist meat by delaying the temperature fall in the carcass after killing. They concluded that the fast process of chilling the carcass post mortem caused a partial reduction in pale colour characteristics of porcine muscle. HALLUNG (I962) confirmed these results.

Because of the relationship shown by LUDVIGSEN (I953, I954, I955) between the colour changes in the skeletal muscles and the concentration of lactic acid in the same muscle, CLAUSEN and NöRTOF'T (I956) introduced an arbitrary colour scale of ro classes to be given on the cross section of the m. L. dorsi cut at the tip of the last rib. This score was introduced in January 1954 and is still used on all test pigs slaughtered. During the period I954-I965 certain environmental and genetic causation factors have been investigated.

As earlier mentioned, WISMER-PEDERSEN (I959) found a phenotypic correlation of $r_{\mathrm{P}}=-0.7 \mathrm{I}$ between the $\mathrm{pH}$ value in the $\mathrm{m}$. $L$. dorsi behind the last rib 45 minutes post mortem and the water holding capacity in the same muscle. Furthermore he found $r_{\mathrm{P}}=-0.86$ between this 45 minutes $\mathrm{pH}$ value and the corresponding concentration of lactic acid; consequently the 45 minutes $\mathrm{pH}$ value was measured on all Danish test pigs from I958 to I962, but due to missing data only the material from the test year I958-59 could be analyzed.

Table I shows the relationship between the Danish colour score and the $45 \mathrm{mi}$ nutes $\mathrm{pH}$, both taken at the tip of the last rib.

\section{ENVIRONMENTAL, FACTORS AFFECTING THE MEAT COLOUR}

Ludvigsen (I954) and Wismer-Pedersen and RiemanN (I960) discussed the importance of preventing the pigs from fighting and biting during transport to the bacon factory in order to reduce the incidence of pale, moist muscles. In I959 the Danish Meat Research Institute developed a halter to be placed on the pigs before delivery at the bacon factory (WICHMAN-JöRGENSEN I959, I96I). This halter was tested on pigs from the three progeny testing stations from January to July I960, and caused a general improvement in the mean of the muscle colour score of the test pigs. ("Sjælland ) : $\mathrm{P} \leqslant 0.20$, "Fyn " : $\mathrm{P} \leqslant$ o.oor, and " Jylland " $\mathrm{P} \leqslant 0.20$ ).

Using halter, the phenotypic variance within the same day of delivery was also decreased, but most in the uncastrated animals, the gilts (table 2). 


\section{TABLE I}

The $p H$ measurement in the $m$. L. dorsi at the tip of the last rib 45 minutes after killing at the different classes for meat colour in the cross section of the $m$. L. dorsi, this cut also made at the tip of the last rib

pH du muscle long dorsal à la dernière côte 45 minutes après l'abattage pour les différentes classes de note de couleur

Specification of the description of the muscle cross section surface $\left(^{1}\right)$

\begin{tabular}{|c|c|c|c|}
\hline \multirow[t]{2}{*}{$\begin{array}{l}\text { Score for } \\
\text { meat colour }\end{array}$} & \multirow[t]{2}{*}{$\begin{array}{c}\mathrm{pH}- \\
\text { measurement }\end{array}$} & \multicolumn{2}{|c|}{$\begin{array}{c}\text { Distribution } \\
\text { of meat colour scores } \\
(\%)\end{array}$} \\
\hline & & $1960-61$ & $1965-66$ \\
\hline & & 4618 & 5257 \\
\hline 0.5 & 5.45 & 0.3 & 0.2 \\
\hline 1.0 & 5.48 & 3.9 & 2.7 \\
\hline 1.5 & 5.56 & 15.9 & 14.5 \\
\hline 2.0 & 5.80 & 22.4 & 22.1 \\
\hline 2.5 & 6.19 & 41.8 & 52.0 \\
\hline 3.0 & 6.25 & 13.9 & 7.9 \\
\hline 3.5 & 6.28 & 1.5 & 0.6 \\
\hline 4.0 & 6.28 & 0.3 & 0 \\
\hline 4.5 & 0 & 0 & 0 \\
\hline 5.0 & 0 & 0 & 0 \\
\hline
\end{tabular}

(1) Nörtoft-Thomsen and Pedersen (1961).

Pronounced too light meat colour........

A little too light meat colour .......... Colour class Per cent

Gray, same colour as boiled meat.

Very moist surface, rough and stringy structure.

Very pale, pinkish, moist surface, rough structure.

Pale pink, slightly moist surface, somewhat rough

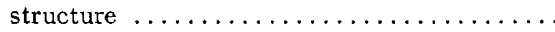

Slightly paler than desirable, almost dry surface and almost normal structure ............

Ideal red colour, dry surface, normal structure. .

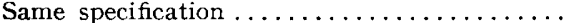

Sightly darker than desirable, dry surface...

Very dark dry

Same specification ....................

Satisfactory meat colour .............

$\begin{array}{ccc}-\overline{5}-1.5 & 20 & 17 \\ 2.0 & 22 & 22 \\ 2.5-4.0 & 58 & 61\end{array}$

TABLE 2

Phenotypic variance of meat colour score within the same day of delivery with and without halter. 4 weeks, January-June 1960

Variance phénotypique de la note de couleur, intra-jour de transport à l'abattoir avec ou sans contention des animaux

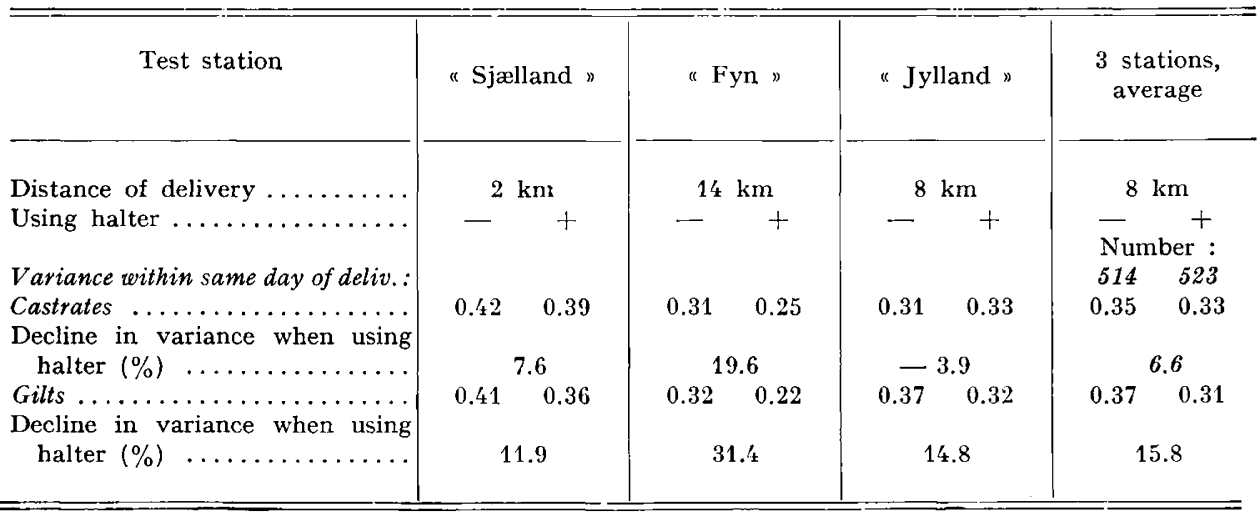


It is clearly shown that the procedure of using halter decreases the variance between pigs delivered on the same lorry, and that the gilts are the most sensible sex, their variance in meat colour score being app. Io per cent larger than that of the castrates. A remarkable effect of the distance ( $\mathrm{km}$ to bacon factory) on the intra week variance in meat colour is demonstrated.

To repeat this examination of the effect of transport stress on both the colour score and the 45 minutes $\mathrm{pH}$ value, an experiment was carried out with 54 test groups (each test group consisted of two castrates and two gilts) to be delivered from the newly established fourth test station to the bacon factory, driving distance being $0.5 \mathrm{~km}$. One gilt and one castrate from each of the 54 test groups were killed in their individual pens and transported dead to the bacon factory, whereas the other gilt and castrate litter mates were transported alive to the factory (NöRTOFI Thomsen, I96I). The results are shown in table 3 .

\section{TABLE 3}

Effect of transport on meat colour

and $45 \mathrm{mn} p H$ in $m$. L. dorsi behind the last rib

(One litter mate in each of the two treatments and in each sex)

Effet du transport sur la couleur de la viande et le pH à $45 \mathrm{mn}$ du muscle long dorsal derrière la derniève côte

(Dans chaque portée un mâle et une femelle ont été attribués à chaque traitement)

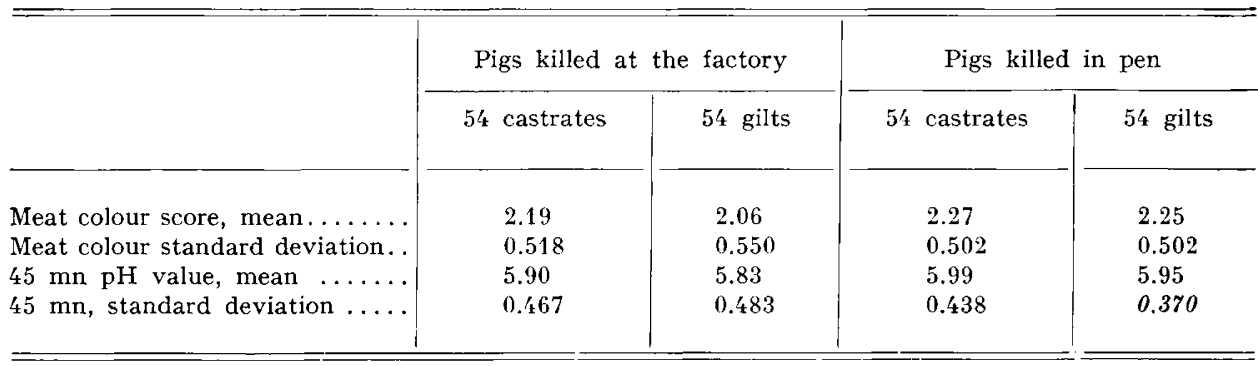

The muscle colour mean was improved in both the castrates and the gilts killed in the pen. The standard deviation within litter and sex decreased in both sexes, but most in the gilts. However, only the standard deviation of the 45 minutes $\mathrm{pH}$ value in the muscle differed significantly in the gilts killed in the pen from that of the gilts killed at the factory $(\mathrm{P} \leqslant 0.048$, table 3$)$.

To investigate the effect of transportation on the meat quality in order to standardize the treatment during transport of not only the test pigs, but also ordinary bacon pigs from commercial producers, the Danish Meat Research Institute has set into operation an experiment in I97I (WICHMANN-JöRGENSEN, I97I).

The effect of season on both the meat colour score and $45 \mathrm{mn} \mathrm{pH}$ in the $\mathrm{m}$. L. dorsi is investigated examining their variances. The effect of the 3 months-season is approximately 5 per cent of the phenotypic variance. In table 4 is given the relative variance of the month and the day of delivery and of the individual test pig for each of six station-sex subgroups within the test year I958-59.

It is clearly shown that 85 to Ioo per cent of the phenotypic variance is deu 


\section{TABLE 4}

Relative importance of month and day of delivery as causes of variance in meat colour score and $45 \mathrm{mn} p H$ in $\mathrm{m}$. L. dorsi

3 testing stations. $1958-59$

Importance relative du mois et du jour de livraison à l'abattoir

dans la variance de la note de couleur et du pH à $45 \mathrm{mn}$ du muscle long dorsal 3 stations. 1958-59

\begin{tabular}{|c|c|c|c|c|c|c|}
\hline \multirow{2}{*}{ Sex } & \multicolumn{2}{|c|}{ "Sjælland" } & \multicolumn{2}{|c|}{ "Fyn " } & \multicolumn{2}{|c|}{ "Jylland" } \\
\hline & Castrates & Gilts & Castrates & Gilts & Castrates & Gilts \\
\hline $\begin{array}{c}\text { Number of test pigs ....... } \\
\text { Meat colour score }\end{array}$ & 584 & 624 & 586 & 624 & 545 & 580 \\
\hline Month, at same station .... & -0.1 & -0.3 & 6.1 & 4.1 & -4.2 & -0.3 \\
\hline $\begin{array}{l}\text { Week day of delivery } \ldots . . \\
\text { Test pig killed on the same }\end{array}$ & 3.7 & -0.7 & 2.8 & -1.2 & 8.6 & 3.6 \\
\hline $\begin{array}{c}\text { day as contemporaries... } \\
455 \mathrm{mn} \mathrm{pH}\end{array}$ & 96.4 & 101.0 & 91.1 & 97.1 & 95.6 & 96.7 \\
\hline Month, at same station .... & $\longrightarrow 0.2$ & 2.9 & 9.2 & 5.1 & $\ldots 1.3$ & 2.8 \\
\hline Week day of delivery $\ldots$. & 13.8 & -0.4 & 4.0 & 5.0 & 8.6 & 7.4 \\
\hline $\begin{array}{l}\text { Test pig killed on the same } \\
\text { day as contemporaries ... }\end{array}$ & 86.5 & 97.5 & 86.8 & 89.9 & 92.7 & 89.9 \\
\hline
\end{tabular}

\section{TABLE 5}

Relation between meat colour and $p H$ in the $m$. L. dorsi on the one side and the chilled carcass weight on the other side

Relation entre la couleur de la viande et le $p H$ du muscle long dorsal d'une part et le poids de la carcasse froide d'autre part

$\overline{\text { —_ }}$

Points for meat colour, 1962-63 (4990 pigs finished the test)

\section{Regression} per $1 \mathrm{~kg}$ chilled carcass weight

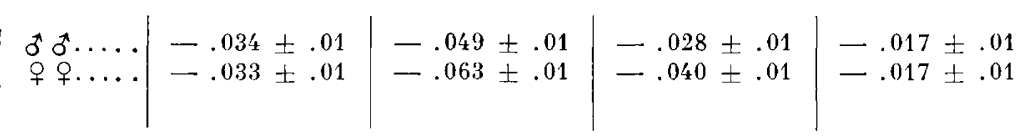

Reduction of the total variance when correcting to the mean chilled carcass weight

\begin{tabular}{|c|c|c|c|c|c|c|c|c|}
\hline $\begin{array}{l}8 \text { year-station-sex } \\
\text { sub-groups of app. } \\
600 \text { pigs each }\end{array}$ & $\%$ & $\begin{array}{c}\text { Mean } \\
(\mathrm{kg})\end{array}$ & $\%$ & $\begin{array}{c}\text { Mean } \\
(\mathrm{kg})\end{array}$ & $\%$ & $\begin{array}{c}\text { Mean } \\
(\mathrm{kg})\end{array}$ & $\%$ & $\begin{array}{c}\text { Mean } \\
(\mathrm{kg})\end{array}$ \\
\hline ates... & 1.7 & 65.0 & 2.5 & 65.3 & 1.0 & 65.2 & 0.4 & 65.3 \\
\hline$\ldots \ldots \ldots \ldots \ldots \ldots$ & 2.1 & 65.4 & 4.8 & 65.6 & 1.7 & 65.3 & 0.3 & 64.4 \\
\hline
\end{tabular}

pH-measurement, 1961-62 (4 998 pigs finished the test)

Regression of the $\mathrm{pH}$-measurement in the $\mathrm{m}$. $L$. dorsi on the chilled carcass weight :

$\mathrm{H}^{+}$power exponents $\left|\delta \delta^{*}.\right|-.040 \pm .008|-.026 \pm .008|-.017 \pm .008 \mid-.014 \pm .009$

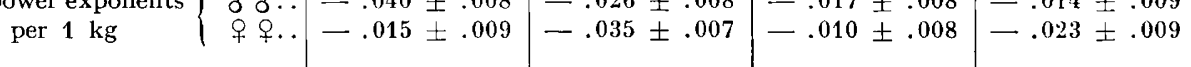


to the difference between the individual reaction among pigs delivered to the bacon factory on the same lorry on the same day.

The influence of outside temperature on the muscle colour score was estimated as the linear regression of the mean muscle colour score on the temperature, measured outside the test stations at noon in $\mathrm{C}^{\circ}$ for all test stations and sexes over four years. The mean temperature of year fluctuated from $7.2 \mathrm{Co}^{\circ}$ to II.o $\mathrm{Co}^{\circ}$, and the regression estimates fluctuated from +0.00002 to -0.02 .24 out of 28 regression coefficients showed a negative influence of the outdoor temperature, the delivery distance of $\mathrm{I} 4 \mathrm{~km}$ showing the strongest influence.

\section{Eflect of chilled carcass weight on muscle colour and $45 \mathrm{mn}$ pH in $\mathrm{m}$. I. dorsi}

Table 5 shows the repeatability of the consistently negative effects of chilled carcass weight on both muscle colour and $\mathrm{pH}$ though these effects are only slight, being of the order between 0.3 per cent and 4.8 per cent of the phenotypic variance.

Similarity in relationship to other characters for the $45 \mathrm{mn} p H$ value and for the meat colour both in the $m$. L. dorsi at the tip of the last rib

In the previous tables $2,3,4$, and 5 it is shown that these two characters have reacted quite similarly against the causative effects mentioned. The reactions of these two characters with a third one are also very similar which is shown in table 6 . The correlation of the residual sector is a measure of the covariation within litters after the elimination of the additive gene effect. The effects of the inter- (epistatic) and intra-(dominant) allelic gene action are included in this correlation.

Meat colour and $\mathrm{pH}$ in the muscle are negatively correlated with fast gain and positively with feed consumption rate. At constant gain the covariation between feed consumption and these two characters is not changed. Length of the pig and all fat measurements are positively correlated with colour and $\mathrm{pH}$ in the muscle whereas meat content is negatively correlated. None of these correlations are strong.

The intra-station phenotypic correlation between the two characters was estimated at +0.68 and +0.7 I for castrates and gilts, respectively. However, it is of more importance that in the same material of I 7I5 castrates and I 8II gilts, the genetic correlation was estimated at $r_{\mathrm{G}}=+0.86$ (48o d. f. for sires).

\section{HERITABILITY ESTIMATES FOR POINTS \\ FOR MEAT COLOUR AND $45 \mathrm{MN}$ PH, BOTH IN THE $M$. L. DORSI AT THE TIP \\ OF THE LAST RIB}

The partitioning of the phenotypic variance of the meat colour score and two other important carcass characteristics are based on the data from I956 to I965 (table 8). This should include a sufficient number of test year - test station - sex subgroups, one year of test comprising material from four test stations, and therefore eight subgroups including app. 9o degrees of freedom for sires. 
The hierarchical structure of these estimates from 1958 to 1965 is : two test pigs of the same sex per test group, five test pigs of the same sex per sire half-sib family, and I 2 test pigs of the same sex per breeding centre (élite herd).

Within the élite herds relationships of 17.5 p. Ioo were found between dams mated to the same sire, and $2.6 \mathrm{p}$. Ioo between sires standing at the same breeding centre.

\section{TABLE 6}

Phenotypic correlations with points for meat colour and the pH-measurement The 3 Pig Progeny Testing Stations, year of test 1958-59

Correction is undertaken for effect from cold carcass weight, seasons of year and test stations

Corrélations phénotypiques avec la couleur de la viande et le pH.

Données des 3 stations de contrôle de la descendance, année 1958-59, corrigées pour le poids de carcasse et les effets de la saison et de la station

\begin{tabular}{|c|c|c|c|c|c|c|c|}
\hline \multirow{2}{*}{$\begin{array}{l}r_{\text {phenotype, d.f. }} \\
r_{\text {residue }} \text { d.f. }\end{array}$} & \multirow{2}{*}{ 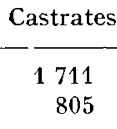 } & \multirow{2}{*}{$\begin{array}{r}\text { Gilts } \\
1807 \\
903\end{array}$} & & \multicolumn{2}{|c|}{$\begin{array}{l}\text { Points for meat colour } \\
\text { in the cross section } \\
\text { of the musc. long. dorsi } i\end{array}$} & \multicolumn{2}{|c|}{$\begin{array}{l}\mathrm{pH} \text {-measurement } \\
\text { in the musc. long. dorst } \\
\text { at the same place }\end{array}$} \\
\hline & & & & $r_{\text {phenotype }}$ & $r_{\text {residue }}$ & $r_{\text {phenotype }}$ & residue \\
\hline \multirow{5}{*}{\multicolumn{3}{|c|}{$\begin{array}{l}\text { Ave. daily gain in grams } \\
\text { from } 20 \text { to } 90 \mathrm{~kg} \text { live weight } \\
\text { Feed consumption (Scand. FU) } \\
\text { per } \mathrm{kg} \text { live weight gain } \\
\text { from } 20 \text { to } 90 \mathrm{~kg} \text { live weight } \\
\text { Feed consumption rate } \\
\text { at constant gain }\end{array}$}} & Castrates & -0.03 & +0.10 & -0.08 & -0.10 \\
\hline & & & Gilts & -0.01 & -0.12 & -0.04 & -0.26 \\
\hline & & & $\begin{array}{c}\text { Castrates } \\
\text { Gilts }\end{array}$ & $\begin{array}{l}+0.06 \\
+0.05\end{array}$ & $\begin{array}{l}-0.02 \\
+0.26\end{array}$ & $\begin{array}{l}+0.12 \\
+0.09\end{array}$ & $\begin{array}{l}+0.13 \\
+0.30\end{array}$ \\
\hline & & & Castrates & +0.07 & -0.02 & +0.11 & +0.11 \\
\hline & & & Gilts & +0.07 & +0.23 & +0.10 & +0.18 \\
\hline \multicolumn{3}{|c|}{ Body length in $\mathrm{cm}$} & $\begin{array}{l}\text { Castrates } \\
\text { Gilts }\end{array}$ & $\begin{array}{l}+0.16 \\
+0.19\end{array}$ & $\begin{array}{l}+0.19 \\
+0.12\end{array}$ & $\begin{array}{l}+0.16 \\
+0.15\end{array}$ & $\begin{array}{l}+0.27 \\
+0.25\end{array}$ \\
\hline \multirow{2}{*}{\multicolumn{3}{|c|}{$\begin{array}{l}\text { Points }(0-15) \text { for size } \\
\text { and shape of hams } \\
\text { Area of the musc. long. dorsi } \\
\text { on the cross section } \\
\text { of the cut bacon side, } \mathrm{cm}^{2}\end{array}$}} & $\begin{array}{l}\text { Castrates } \\
\text { Gilts }\end{array}$ & $\begin{array}{l}-0.19 \\
-0.28\end{array}$ & $\begin{array}{l}-0.13 \\
-0.05\end{array}$ & $\begin{array}{l}-0.29 \\
-0.27\end{array}$ & $\begin{array}{l}-0.12 \\
-0.03\end{array}$ \\
\hline & & & $\begin{array}{l}\text { Castrates } \\
\text { Gilts }\end{array}$ & $\begin{array}{l}-0.14 \\
-0.14\end{array}$ & $\begin{array}{l}-0.06 \\
-0.11\end{array}$ & $\begin{array}{l}-0.17 \\
-0.14\end{array}$ & $\begin{array}{l}-0.16 \\
-0.10\end{array}$ \\
\hline \multirow{3}{*}{\multicolumn{3}{|c|}{$\begin{array}{l}\text { Are of fat on the cross section } \\
\text { of the cut bacon side, } \mathrm{cm}^{2} \\
\text { Mid-back measurement, } \mathrm{cm} \\
\text { Side fat measurement } \\
\text { on the cross section } \\
\text { of the cut bacon side, } \mathrm{cm}^{2}\end{array}$}} & Castrates & +0.09 & -0.15 & +0.19 & +0.11 \\
\hline & & & $\begin{array}{c}\text { Castrates } \\
\text { Gilts }\end{array}$ & $\begin{aligned}+ & 0.02 \\
+ & 0.05\end{aligned}$ & $\begin{array}{r}-0.36 \\
-0.27\end{array}$ & $\begin{array}{r}+0.05 \\
+0.07\end{array}$ & $\begin{array}{r}-0.29 \\
-0.40\end{array}$ \\
\hline & & & $\begin{array}{c}\text { Castrates } \\
\text { Gilts }\end{array}$ & $\begin{array}{l}+0.07 \\
+0.10\end{array}$ & $\begin{array}{l}-0.30 \\
-0.02\end{array}$ & $\begin{array}{l}+0.18 \\
+0.16\end{array}$ & $\begin{array}{l}+0.02 \\
-0.11\end{array}$ \\
\hline \multicolumn{3}{|c|}{$\begin{array}{l}\mathrm{pH} \text {-measurement in the musc. } \\
\text { long. dorsi at the last rib }\end{array}$} & $\begin{array}{l}\text { Castrates } \\
\text { Gilts }\end{array}$ & $\begin{array}{l}+0.66 \\
+0.71\end{array}$ & $\begin{array}{l}+0.68 \\
+0.57\end{array}$ & & \\
\hline
\end{tabular}

Thus the data in tables 7 and 8 are corrected for the effect of the relationship between sires and for that between dams ; further for the influence of chilled carcass weight, seasons of year, progeny test stations, and year of test.

The $\mathrm{pH}$ value, measured 45 minutes after killing, is included in the international recognized criteria for classifying a pig carcass to be either normal or PSE 
(e. g. Dutson et al., I97I). In table 7 are given the results of the only complete test year in respect to data set including this criterion for meat quality. This is the same set of data as used for the results in table 6 .

An essential fact in table 7 is the characteristic higher heritability in both criteria for the gilts than for the castrates in this sample. However, this dramatic difference between sexes is undoubtedly due to sampling variation as it is not found over the 9 years period I956-I965 for the meat colour score (table 8 ; castrates : $h^{2}=0.27 \pm 0.06$, gilts : $\left.h^{2}=0.36 \pm 0.06\right)$.

\section{TABLE 7}

Analysis of variance of points for meat colour and the $45 \mathrm{mn} p H$ measurement both in the $m$. L. dorsi Test year 1958-59

Analyse de variance de la note de couleur et du pH à $45 \mathrm{mn}$ du muscle long dorsal Année 1958-59

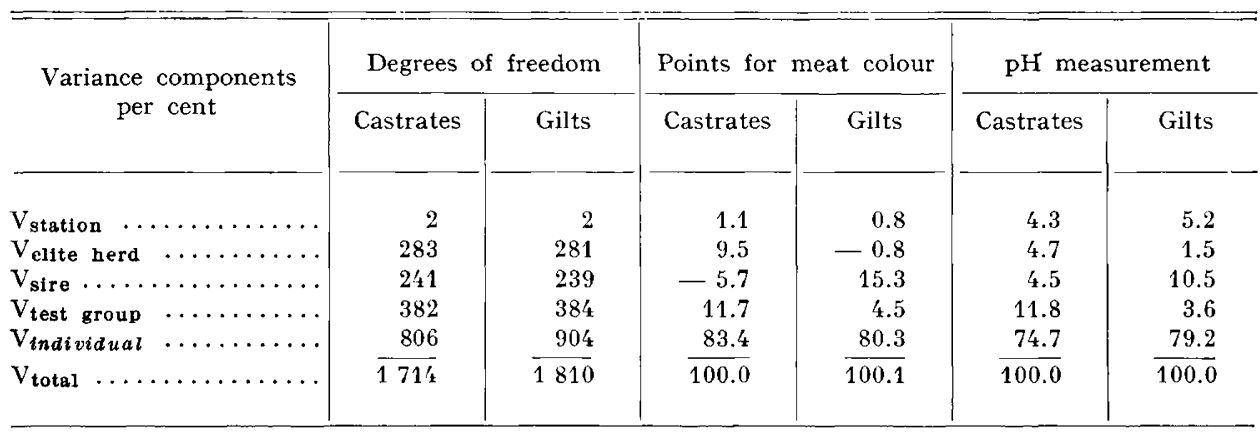

Points for meat colour.

$$
\begin{aligned}
\text { Castrates }: \bar{y} & =2.35 \pm 0.013 ; \\
s_{y} & =0.533, \text { sintra litter }=0.488 ; \\
p H \text { measurement } & \\
\text { Castrates : } \bar{y} & =6.07 \pm 0.008 \\
s_{y} & =0.350, \text { sintra litter }=0.305
\end{aligned}
$$

\begin{tabular}{|c|c|c|c|c|}
\hline \multirow{2}{*}{ Causation components, per cent } & \multicolumn{2}{|c|}{ Points for meat colour } & \multicolumn{2}{|c|}{$\mathrm{pH}$ measurement } \\
\hline & Castrates & Gilts & Castrates & Gilts \\
\hline Breeding center (i.e. herd) environment $\left(c^{2}\right)$, per cent & 10.8 & -4.0 & 3.9 & -0.7 \\
\hline Heritability or additive gene effect $\left(h^{2}\right)$, per cent $\ldots$ & -23.6 & 63.4 & 19.4 & 45.3 \\
\hline Maternal effect, litter environment $\left(l^{2}\right)$, per cent $\ldots$ & 16.7 & -8.6 & 8.4 & -5.5 \\
\hline Residue, i.e. $\%$ error variance $\left(e^{2}\right)$, per cent $\ldots \ldots \ldots$ & 96.1 & 49.2 & 68.3 & 60.9 \\
\hline 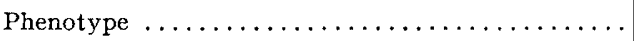 & $\overline{100.0}$ & $\overline{100.0}$ & $\overline{100.0}$ & $\overline{100.0}$ \\
\hline
\end{tabular}

As an average between the two sexes, an estimate of $h^{2}=0.32$ for the $45 \mathrm{mn}$ $\mathrm{pH}$ value (table 7 ) is a moderately high heritability, indicating that the additive gene effect is controlling the structural conditions in the pig; WISMER-PEDERSEN 

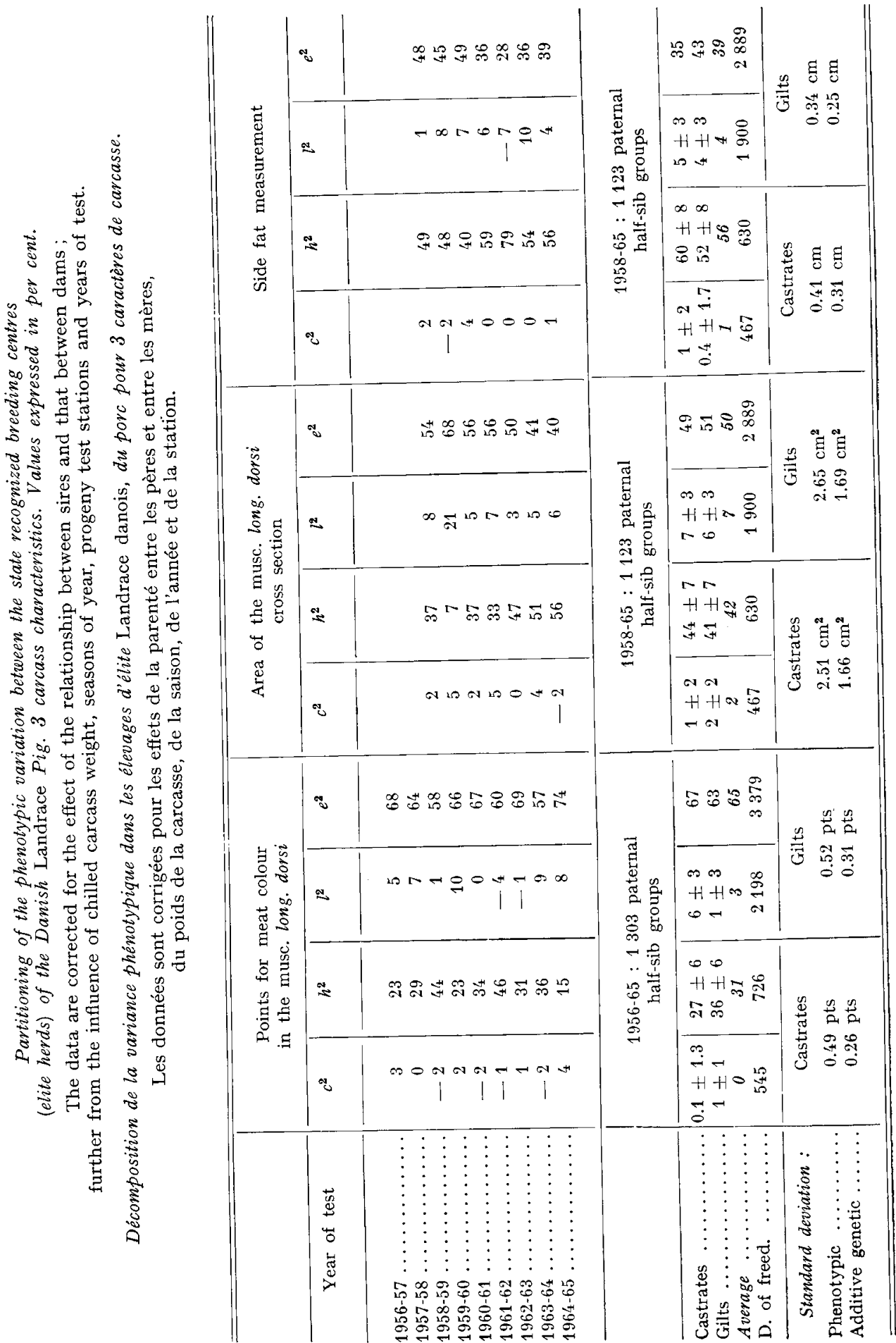
having demonstrated a fairly high phenotypic correlation of $r_{P}=-0.7 \mathrm{I}$ between this $45 \mathrm{mn} \mathrm{pH}$ value and the water holding capacity.

The best estimate of the partitioning of the phenotypic variance in the Danish Landrace pig in the period prior to 1967 is given in table 8 for three characters which are important for the selection of bacon type.

PEDERSEN (I964) found that the m. L. dorsi area controls app. 25 p. Ioo of the lean meat content in the carcass $\left(r_{\mathrm{P}}(\right.$ castrates $)=+0.44$ and $r_{\mathrm{P}}\left(\right.$ gilts $\left.\left._{\mathrm{i}}\right)=+0.49\right)$, whereas he found that the side fat measurement controls $50 \mathrm{p}$. Ioo of the lean meat content in the carcass $\left\langle\boldsymbol{r}_{\mathrm{P}}(\right.$ castrates $)=-0.7 \mathrm{I}$ and $\left.\boldsymbol{r}_{\mathrm{P}}\left({ }_{\text {gilts }}\right)=-0.68\right)$.

That is the reason why these two characters are included in table 8 together with the meat colour score.

Difference between sexes is not found in the colour score mean like in the two other characteristics, but the phenotypic standard deviation as well as the genetic one differ between the two sexes in all characters as demonstraded in the tables 7 and 8 . This difference in variance is about $8 \mathrm{p}$. IOO, and a similar difference is found in the score for nasal alterations :

Meat colour score:

1956-60

$s^{2}{ }_{\text {intra litter }}$ (gilts) $/ s^{2}{ }_{\text {intra }}$ itter (castrates) $=0.235 / 0.2 \mathrm{I} 7=1.08$.

Nasal alterations (rhinitis score):

\section{6-60}

$$
s_{r}^{2} \text { (gilts) } / s_{\mathrm{P}}^{2} \text { (castrates) }=0.824 / 0.735=1.12 \text {. }
$$

In table 8 it is clearly demonstrated that under a system of test, where it is necessary to restrict the material so that only a little more than five pigs per sire half-sib family and only I2 pigs per herd is obtained, it is necessary to include a number of test years to get sufficient unbiased estimates of the population parameters in the breed. This agrees with the theory given by RoBERTSON (I960) about experimental design on the measurement of heritabilities.

Besides having a sufficient number of individuals per subgroup to get unbiased estimates of the different intra-class correlations, the years must cover some sire generations because the sample of paternal half sib groups sent to the test station per year is not necessarily representative for the potentialities of zygotes from the breeding centres as a whole.

Sex differences in the heritabilities are not demonstrated in the muscle arae and the side fat measurement in the overall estimates within test stations and years. In the points for meat colour it should be concluded that the sire component estimated from the castrates data tends to be decreased and, therefore, the "litter environment " and the error variance is correspondingly increased. In a breeding program it should, therefore, be more efficient to base the selection on data from uncastrated animals.

It has been shown previously that the effects test stations, seasons of year, and chilled carcass weight are affecting the meat colour only slightly (tables 5 and 7 ). Table 8 shows that the only two causations which matter for the meat colour is the heritability and the residual error. If only gilts are included in the selection program, it is realistic to work with a heritability of 0.4 and a residual error of 0.6 . 
If both sexes are included in the test group, the heritability is 0.3 and the residual error is 0.7 .

A rather strong maternal effect is found in the muscle area. This could to some extent be due to mothering abilities of prenatal nature.

\section{GENETIC COVARIATION BETWEEN}

THE TWO SEXES IN POINTS FOR MEAT COLOUR

AND TWO OTHER TRAITS

The test groups of the litters from the state recognized breeding centres consist of 2 castrated males and 2 females. Because of the uncertainty of the genetic variance of the meat colour in the castrates and also because the genetic improvement of a character is increased per year when only using 2 instead of 4 litter mates due to the increased selection intensity, it was of interest to investigate the genetic correlation between the two sexes with respect to their performance in the three carcass characteristics (table 9) (Jonsson, I97 I b).

\section{TABLE 9}

Genetic correlation and expected genetic improvement of two carcass quality characters and of one meat quality character

Corrélation génétique et amélioration génétique espérée et d'un critère de qualité de la viande

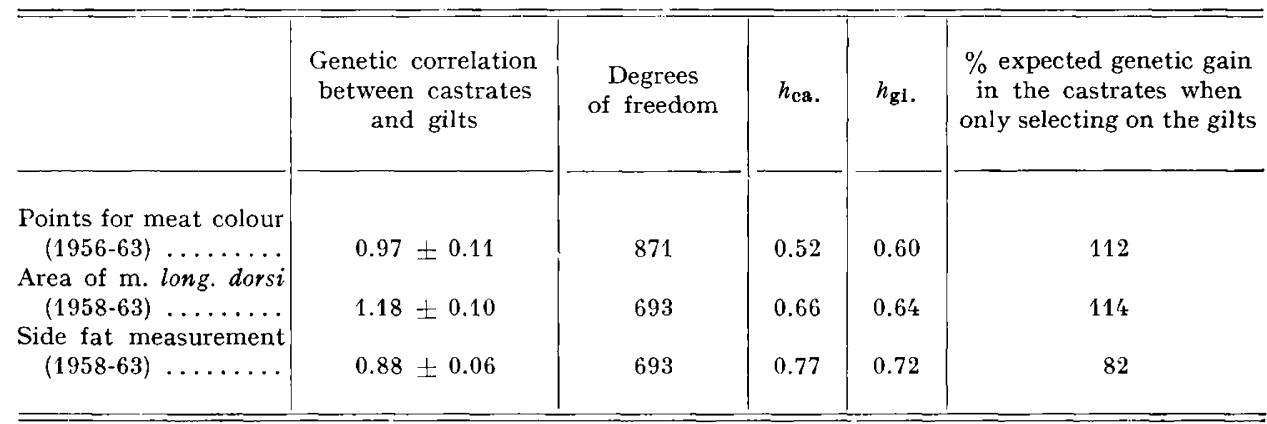

The variance components for the interaction between sire half-sib families and the two sexes were very small in the meat colour score and in the side fat measurement, 0.0034 points $^{2}$ and $0.0028 \mathrm{~cm}^{2}$, respectively; the F-quotients were $\mathrm{I}, 09$ and I.I5, respectively. This is the reason why the corresponding genetic correlations are not unity. In the musc. Long. dorsi area, however, the F-quotient was consistently beneath unity in the different test year-test station subgroups, so no sire-sex interaction is found in this character. 


\section{PHENOTYPIC AND GENETIC VARIATION \\ AND COVARIATION IN SOME IMPORTANT \\ CARCASS AND MEAT CHARACTERISTICS}

IN THE DANISH LANDRACE PIG

The two Danish carcass evaluation centres were started in I967 to investigate the new characters for carcass quality which were to be recorded at these centres.

The material comprised 1403 gilts and 1400 castrates. As this first investigation on the new carcass characteristics was planned so that sires would be tested on at least two test groups (two gilts and two castrates per test group ; it was not possible, as originally planned, to set the limit at three test groups), it was impossible to include the variation between breeding centres in the hierarchical classification. So any carry-over effect from breeding centres will be included in the sire component. The hierarchical structure of the analysis was as follows :

\begin{tabular}{|c|c|c|}
\hline Source of variation & $\begin{array}{c}\text { 1967-69 } \\
\text { d. f. }\end{array}$ & Expected mean squares \\
\hline $\begin{array}{l}\text { Between sires within carcass evaluation } \\
\text { centres and sex sub groups } \ldots \ldots \ldots \ldots \\
\text { Between test-groups within sires } \ldots \ldots \ldots \ldots \\
\text { Between full-sibs of the same sex....... }\end{array}$ & $\begin{array}{r}456 \\
1005 \\
1338\end{array}$ & $\begin{array}{l}\sigma_{e}^{2}+1.9^{\prime} \sigma^{2} \text { litter }+6.08 \sigma^{2} \text { sire } \\
\sigma_{e}^{2}+1.90 \sigma^{2} \text { litter } \\
\sigma_{e}^{2}\end{array}$ \\
\hline
\end{tabular}

The standard errors for the heritability estimates were computed according to the method given by B. Wool,F (FALCONER, I963) as shown in Jonsson (I97I $a$ ).

The per cent of lean meat in the entire carcass side (character 9) is predicted by Io individual carcass measurements and weights, including cold carcass weight and sex. The side fat measurement is a prominent $x$-variable in the prediction equation, controlling app. 50 per cent of the lean content in the entire side. $\mathrm{R}=0.87$ (ClaUSEN et al., I968). Table ro gives the phenotypic and genetic population parameter estimates in the Danish Landrace pig for six traditional and six new carcass quality characters introduced at the two carcass evaluation centres.

For the average backfat thickness the magnitude of heritability given in table ro seems to be more reasonable, and for the $\mathrm{m}$. L. dorsi area the value given in table 8 seems more reasonable. An estimate of $h^{2} \sim 0.62$ seems too high for the area of m. L. dorsi; this should also be the case for characters nr. 6,8 and 9 in table ro.

One reason for this must be the lack of including the class for "breeding centres " in the hierarchy and the lack of having corrected for seasonal differences. The period of investigation is perhaps also a little short. The élite breeders have given considerable attention to the three characters $m$. L. dorsi area, side-fat measurement and per cent lean meat in the entire side from I 967 and onwards. This means that the 


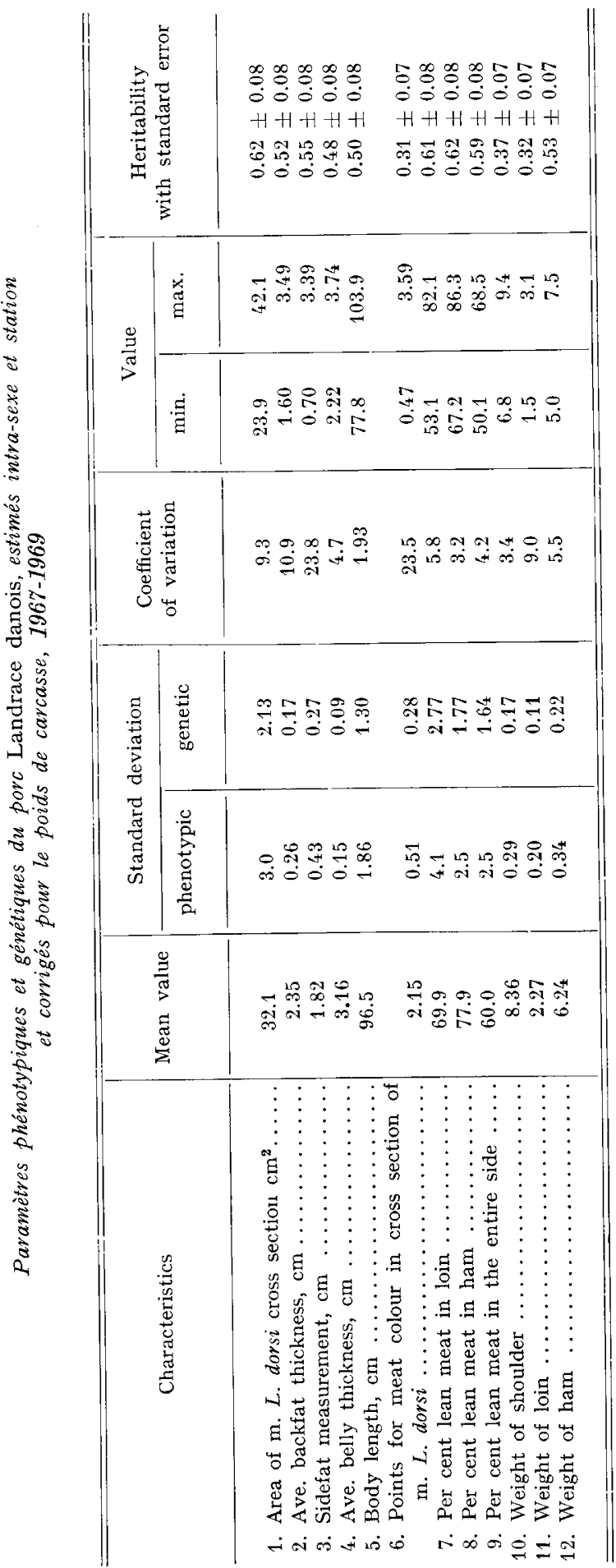


effect of selection is included in the differences between sires' half-sib groups. Having included more years and corrected for effects from seasons and years, and having included the classification breeding centres in the hierarchy, a probable upward bias will be corrected for.

But the estimates for the additive gene effect in table ro show that no lack of additive genetic variability in the breed ecists, which is also confirmed by the estimates given by STAUN (I968) and STAUN and JENSEN (I970) for the same breed. Their heritability estimates for the same characters, estimated from the data from the pig progeny testing stations, rank from 0.46 to 0.78 .

The magnitude of the genetic standard deviation and the coefficient of variation for the important characters is striking.

Heritability estimates for colour values reported from other breeds range from $0.18 \pm 0.06$ for Norwegian Landrace (LANGHOLZ, I966) over $0.25 \pm 0.09$ for Large White (PEASE and SMITH, I965), $0.28 \pm 0.15$ (JENSEN et al., I967) as an estimate within the breeds Duroc, Yorkshire, Hampshire, Poland China, and Spotted Swine breeds, to $0.3^{8} \pm 0$. Io for Deutsches veredeltes Landschwein (FLOCK, I968). These estimates are similar to the present estimate given for the character 6 .

In Denmark cross breeding experiments between the pig breeds Large White and Danish Landrace are planned. One of the main subjects to be investigated is the hypothesis of dominant gene effect on meat quality characteristics. SyBEsma (I970) has suggested that Cross breeding different breeds is a very promising means of improving meat quality.

WISMER-PEDERSEN (I959) found a correlation of $r_{P}=0.7$ I between $45 \mathrm{mn}$ $\mathrm{pH}$ and 24 hours water holding capacity, both characters giving a reasonable accurate measure of structural conditions in the tissue. WENIGER et al. (I970, reported from WEISS, I967) found heritability estimates of $h^{2}=0.37 \pm 0.14$ for WHC (centrifuging) and $h^{2}=0.19 \pm 0.10$ for $45 \mathrm{mn} \mathrm{pH}$ value. The estimates of heritability given among others by WENIGER et al. (I970) for the WHC of $h^{2}=0.37 \pm 0.14$ and that for the $45 \mathrm{mn} \mathrm{pH}$ value of $h^{2}=0.32$ from table 7 are supporting the hypothesis that structural conditions in the muscle as a meat quality criterion is controlled by additive gene effect, and, therefore, can be included in a selection program for improvement of meat quality.

In table II, the traditional meat and carcass quality characters are given. The genetic correlations are given below the diagonal and the phenotypic correlations are given above the diagonal.

It is doubtful, whether the positive genetic correlation between colour brightness and muscle size still exists in the Danish Landrace pig, as reported by Jonsson (I97 $\mathrm{x} a$ ). This change in sign could have been forced by a change in gene frequency in the Danish Landrace pig because of a more direct selection for meat content during the recent years. Table II gives the correlation values as follows :

$$
\begin{array}{ccc}
\text { Correlation between } & r_{\mathrm{P}} & r_{\mathrm{G}} \\
- & - & - \\
\text { Points for meat colour in m. L. dorsi } & & \\
\times \mathrm{m} . \text { L. dorsi area } & -0.08 & -0.29
\end{array}
$$

This correlation is slight, but indicates a negative trend.

The negative trend between muscle colour and size of muscle agrees with 


\begin{tabular}{|c|c|c|}
\hline & I & 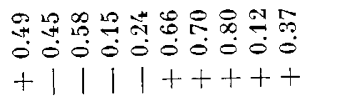 \\
\hline 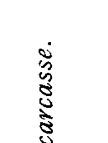 & $=$ & 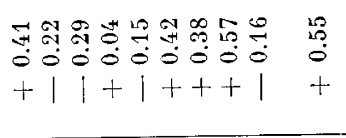 \\
\hline 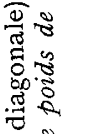 & 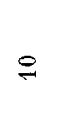 & 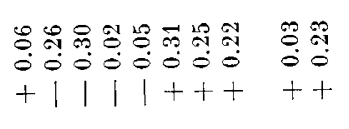 \\
\hline 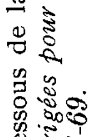 & $\infty$ & 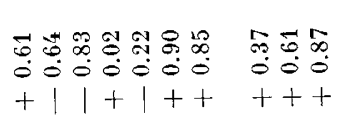 \\
\hline 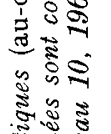 & $\infty$ & 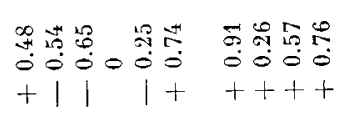 \\
\hline 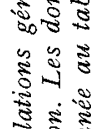 & n & 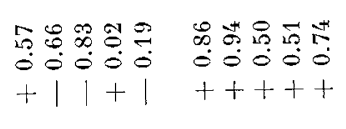 \\
\hline 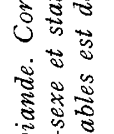 & $\infty$ & 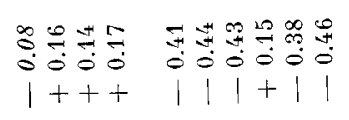 \\
\hline 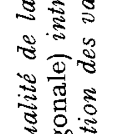 & 10 & 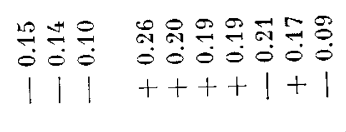 \\
\hline 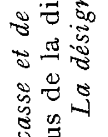 & $\infty$ & 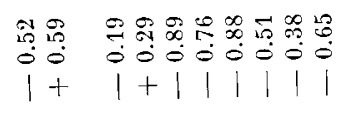 \\
\hline 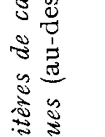 & N & 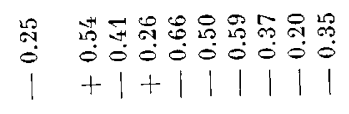 \\
\hline है & $\rightarrow$ & 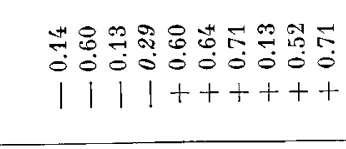 \\
\hline & 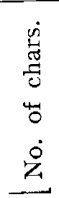 & 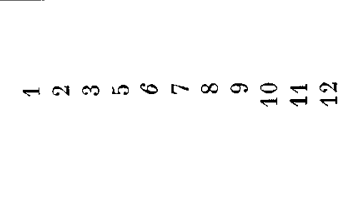 \\
\hline
\end{tabular}


estimates from other breeds, e. g. with that given by FLOCK (I968), who estimated $r_{\mathrm{P}}=-0.28$ and $r_{\mathrm{G}}=-0.56$ between these two characters in the German veredeltes Landschwein breed.

\section{DISCUSSION}

In tables $2,3,4$, and 5 it is demonstrated that the average environment has only a slight effect on the meat colour in the carcass. For the Danish Landrace pig table 7,8 and Io show together with estimates from other breeds that brightness of colour is influenced to a moderate degree by additive gene action, heritability estimates being of a magnitude of $h^{2} \sim 0.3$ for colour values.

The high genetic correlation between sexes in meat colour as well as in other characters important for value of the carcass tells that including only one in the family selection for carcass and for meat evaluation ensures equal genetic progress in the other sex.

However, the problem of structure in meat tissue is not connected with muscle colour. It is, however, significantly related to the stress syndrome as reported e. $\mathrm{g}$. by Ludvigsen (I968 $a$ and I968 b), JUdGe (I969), Steinhauf et al. (I969), BRiskey and Lister (I968), HAase and Steinhauf (I97I), Staun (I968), and many others.

Undoubtedly, it is only a matter of technique to be able to obtain sufficient accurate and repeatable WHC values to ensure reasonably high heritability estimates to be included in selection programs for improvement of the meat structure, genetically.

But all these characters have only a secondary effect on the adaptability of the pig to environmental stress conditions. The main problem of the future must be to lay open the characteristics of the stress syndrome in the pig and the genetic effect behind these adaptation characters. In this way the question can be answered, whether the problem of quality and death losses, as reported from many countries (e. g. by WENIGER et al., I970) can be fought against by means of selection within the breed populations and/or by means of crossing between breeds utilizing a probable heterosis, or may be be mastered through environmental measures.

GERRITS et al. (I969) have shown that intense selection for meatiness in pigs has a significant correlated response to growth hormone concentration. Considerable need exists for more selection experiments like this cited to lay open these problems.

Reçu pour publication en septembre 1971.

\section{RÉSUMÉ}

\section{ASPECTS GÉNÉTIQUES DE LA QUALITÉ DE LA VIANDE CHEZ LE PORC}

Les recherches effectuées au Danemark ont montré que l'influence des conditions ambiantes, telles que la période de l'année, la température pendant le transport et le poids de la carcasse, sur un assez grand nombre d'animaux examinés est faible, du moins sur la variance de la couleur de la viande dans le muscle. 
Les recherches à l'intérieur de nombreuses races porcines, y compris les recherches effectuées au Danemark sur les animaux de la Landrace danoise, ont permis d'évaluer à $h^{2}=0,4$ et $h^{2}=0,3$ les actions additives de gènes pour les valeurs du pH après 45 minutes et celles de la couleur de la viande, toutes les deux mesurées sur les muscles dorsaux à l'extrémité de la dernière côte. Le matériel animal suivant a été employé pour ces recherches : matériel de I958-59 pour les valeurs du $\mathrm{pH}$ après 45 minutes et le pointage de la couleur de la viande, matériel de 1956 à I 965 pour le pointage de la couleur de la viande et matériel de 1967-69 également pour le pointage de la couleur de la viande.

On donne la corrélation génétique entre les sexes en ce qui concerne la couleur de la viande et deux autres caractères.

On donne en outre la variabilité phénotypique et génétique des caractéristiques relatives à la qualité de la viande ainsi que les mensurations objectives de la carcasse, et on examine la relation phénotypique et génétique existant entre ces caractéristiques.

On étudie également la possibilité de venir à bout, au moyen d'un programme de sélection approprié, du problème de la qualité de la viande ainsi que de celui de l'adaptabilité aux stress, qui s'y rattache.

\section{RÉFÉRENCES BIBLIOGRAPHIQUES}

BEck N., I93I. I9. beretning om sammenlignende forsög med svin fra statsanerkendte avlscentre I39. beretning fra forsögslaboratoriet, Köbenhavn, $184 \mathrm{pp}$.

BRISKEY E. J., Lister D., I968. Influence of stress syndrome on chemical and physical characteristics of muscle post mortem. In : D. G. TOPEL, The Pork Industry, Problems and progress. Iowa State University Press, Ames, Iowa. XIV, 236 pp.

Clausen H., Nörtoft Thomsen R., I956. 44. beretning om sammenlignende forsög med svin fra statsanerkendte avlscentre. 288. beretning fra forsögslaboratoriet, Köbenhavn, $\mathrm{r} 50 \mathrm{pp}$.

Clausen H., Nörtoft Thomsen R., I960. 48. beretning om sammenlignende forsög med svin fra statsanerkendte avlscentre. 3I7. beretning fra forsögslaboratoriet, Köbenhavn, I27 pp.

Clausen H., Nörtoft Thomsen R., Pedersen O. K., I968. 56 . beretning om sammenlignende forsög med svin fra statsanerkendte avlscentre. 364. beretning fra forsögslaboratoriet, Köbenhavn* I77 pp.

Dutson T. R., Pearson A. M., Merkel R. A., Koch D. E., Weatherspoon J. B., I971. Histochemical activity of some lysosomal enzymes in normal and in pale, soft and exudative pig muscle. J. Animal. Sci., 32, 233-238.

FAlConer D. S., 1963. Quantitative inheritance. In W. J. Burdette : Methodology in mammalian genetics, $193-216$.

FLock D. K., 1968. Farbhelligkeit in musculus longissimus dorsi als Selektionsmerkmal beim Schwein Die Fleischwirtschaft, 48, 1362-1365.

Frede W., I926. Toxische Herzerkrankung bei Schweinen. Deutsche tieräratliche Wochenschrift, 34, 658-659.

Gerrits R. J., Hetzer H. O., Richardson G. V., I969. Growth hormone potency in lines of swine selected for high and low backfat. Abstract, $J$. Animal Sci., 28, 873.

HaAse S., Steinhauf D., I971. Effects of stress on some oxygen metabolism parameters in boars. 2. International symposium on condition and meat quality in pigs given at the Research Institute for Animal Husbandry, "Schoonoord ", Zeist, March 22-24, 1971.

Hallund O., I 962 . Ködfarvens afhaengighed af köleforlöbet. Not published research data, Danish Meat Research Institute, Roskilde.

Herter M., Wilsdorf G., I9I4. Die Bedeutung des Schweines für die Fleischversorgung. Deutsche Landwirtschaftgesellschaft, Berlin, XVII + 38r pp.

Hupka E., 1939. Seuchenhaft auftretende hühnerfleischähnliche Muskelentartungen unter den Schweinen. Deutsche tieräratliche Wochenschrift, 47, 242-244.

Jensen P., Craig H. B., Robison O. W., 1967. Phenotypic and genetic associations among carcass traits of swine. J. Animal Sci., 26, 1252-1660.

Jonsson P., I97 i a. Population parameter estimates of the Danish Landrace Pig. Acta Agr. Scand. 21, II-I6.

Jonsson P., I97r b. Model computation on future expectation of genetic gain. Acta Agr. Scand., 21, $17-25$.

JUDGE M. D., r969. Environmental stress and meat quality. J. Animal Sci., 28, 755-759.

LANGHOzz H.-J., I966. Das züchterische Hilfsmittel der stationären Nachkommenprüfung beim Schwein III. Heritabilitäten und genetische Korrelationen beim norwegischen Landschwein. Acta Agr. Scand., 16, 97-II4. 
Ludvigsen J. B., I953. Muscular degeneration in hogs (preliminary report). 15. Intern. Vet. Congress, proc. repr., Stockholm.

LUdvigSEN J. B., I954. Undersögelse over den såkaldte muskeldegeneration hos svin. 272. Beretning fra fcrsögslaboratoriet. Köbenhavn, I 12 pp.

Ludvigsen J.B., I955. Undersögelse over den såkaldte muskeldegeneration hos svin III. 279. Beretning fra forsögslaboratcriet, Köbenhavn, 6o pp.

LUDVigsen J. B., I968 a. Vaegt af skjoldbruskkirtel og binyre hos forskellige griseracer of frekvensen af lys og vaeskedrivende skeletmuskulatur. In : Landökonomisk Forsögslaboratoriums Efterårsmöde Årbog. I968, 390-395.

LUDVigsen J. B., I968 b. Virkningen af binyrebarkhormoner på $\mathrm{pH}$ og temperatur i muskulatur hos stress-fölsomme grise. In : Landökonomisk Forsögslaboratoriums Efterårsmöde, Årbog, 1968, 395-399.

NÖRTOFT-THOMSEN, I96I. De sammenlignende forsög med svin fra statsanerkendte aviscentre, year of test Sept. I, I960-Aug. 3I, I96r : In : Landökonomisk Forsögslaboratoriums Efterårsmöde, Ârbog, I96I, 202-2II.

Nörtoft-Thomsen R., Pedersen O. K., I961. Examination of the measurements and assessments made on the back rasher with particular reference to slight of lean and muscle degeneration. E.A.A.P., Pig SubCommission, Rome.

Pease A. H. R., Smith C., 1965. A note on the heritability of muscle colour in pigs. Animal Prod., 7, 273-274.

Pedersen O. K., I964. Bestemmelse af svinenes slagtekvalitet. In : Landökonomisk Forsögslaboratoriums Efterårsmöde, Årbog, 1964, 257-267.

Robertson A., I96o. In : O. Kempthorne, Biometrical Genetics, Pergamon Press, London, VII $+234 \mathrm{pp}$.

Staun H., r968. Muskelfibrenes diameter og antal samt deres betydning for ködfylde og ködkvalitet hos svin af Dansk Landrace. Köbenhavn, $121 \mathrm{pp}$.

Staun H., 197I. Methods of measuring stress in live pigs. Third ad hoc consultation meeting on animal genetic resources. Copenhagen, April 19-23, I97x.

Staun H., Jensen P., I97o. Arvens betydning for ködindhold og ködkvalitet hos svin. In : Landökonomisk Forsögslaboratoriums, Årbog, I970, $12 \mathrm{I}-125$.

Steinhauf D., Weniger J. H., Hoppenbrock K. H., I969. Stressresistenz als Leistungsmerkmal beim Schwein. Züchtungskunde, 41, 93-III.

Sybesma W., 1970. In : Minutes of the session of the commission on pig production, E.A.A.P., Gödöllö, Hungary, r970.

Weiss F. K., I967. Merkmale der Fleischbeschaffenheit beim Schwein, ihre Erblichkeit und ihre Beziehungen zu Mastleistung und Schlachtkörperwert. Diss. Göttingen, I967.

Weniger J. H., Steinhauf D., Glodek P., ig7o. Meat quality as a selection criterion in the pig. Zeitschr. Tierz. Zücht Biol., 87, $230-239$.

WiCHMANN-JÖRGENSEN T., I959. Use of halters during transport and penning of pigs for slaughter. Not published material, Danish Meat Research Institute, Roskilde.

WichmanN-JÖRGENSEN T., I961. The experiment with halters at the Langeland bacon factory. Not published material, Danish Meat Research Institute, Roskilde.

Wichmann-Jorgensen T., I97I. Personal communication.

Wismer-Pedersen J., I959. Quality of pork in relation to rate of pH change post mortem. Food Research, 24, 71 I-727.

Wismer-Pedersen J., Briskey E. J., I96I. Relationship of post mortem acidity and temperure. Food Technology, 15, 232-236.

Wismer-Pedersen J., RiemanN H., rg6o. Pre-slaughter treatment of pigs as it influences meat quality and stability. Proc. 12. Res. Conf. Americ. Meat Inst. Found., University of Chicago, 89-106. 